\title{
Irenaeus's knowledge of the Gospel of Judas: Real or false? An analysis of the evidence in context
}

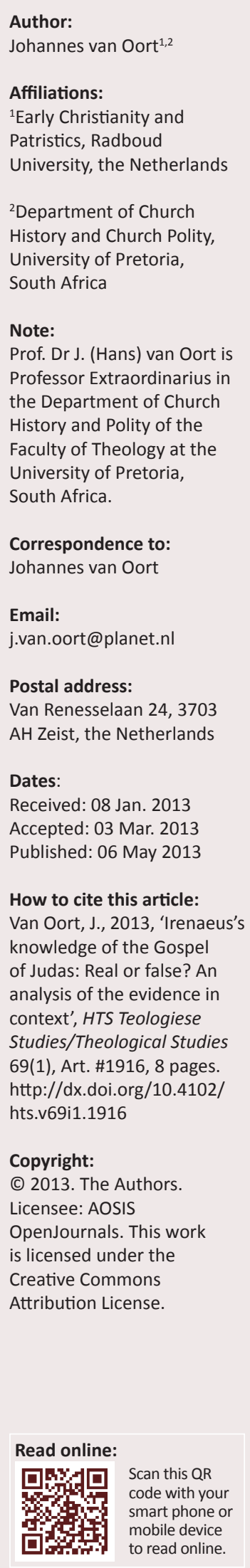

This study discusses Irenaeus of Lyon's testimony of the famous Gospel of Judas, offering both a historical and, in particular, linguistic analysis and retranslation of Against Heresies 1.31.1. On the basis of a detailed philological commentary and textual analysis it is - contrary to most current opinions - concluded that Irenaeus, in all feasibility, had first-hand knowledge of the Gospel and its contents. In other words, Irenaeus appears to have read the text as we now have it ('a composed work') and he summarises it in his treatise. According to Irenaeus's testimony, the Gospel was produced by a group of 2nd century Gnostics who positively venerated Judas as a fellow Gnostic in the same way that they positively venerated Cain. It was because of his particular knowledge of the redeeming act of Sophia as well as the negative characteristics of the creator God in contrast to the superior God that Judas accomplished the 'mystery of his (= Jesus') betrayal', so that 'through him (= Judas) all things, both earthly and heavenly, have been dissolved.'

As far as we can tell, the first person in history to give testimony about a certain Gospel of Judas (best editions and studies: Kasser \& Wurst 2007; Brankaer \& Bethge 2007; Scopello 2008; DeConick 2009; Jenott 2011), was Irenaeus of Lyon (c. 180-185 CE). His testimony has been mentioned often in recent publications and sometimes even discussed at length (Wurst 2006, 2008). For reasons that will become clear, however, a closer rereading of the particular passage in Irenaeus's Adversus Haereses (Against Heresies) is justified. Such a rereading will be cognisant of both the literary context in which the passage appears and of its relation to other patristic testimonies.

Irenaeus speaks about the Gospel of Judas at the end of his first book, Against Heresies, in a passage immediately following his description of the Valentinians's ancestors. After presenting an overview of Gnostic doctrines, beginning with the arch-heretic, Simon Magus, and concluding with the Gnostics typically known as the 'Ophites', he wraps up by saying: 'Such are the opinions current among those people, from which opinions, like the Lernaean hydra, a many-headed beast has been generated: the school of Valentinus ...' (Adv. haer. I, 30, 15). ${ }^{1}$

Irenaeus then proceeds by discussing the alii, [others] (i.e. other Gnostics). ${ }^{2}$ Modern editions and translations have, rather misleadingly, printed the passage in question as the first paragraph of a new chapter. It should be noted, however, that the division of Adversus Haereses into chapters and paragraphs with their various (sub)headings does not stem from Irenaeus, but was added later (cf. e.g. SC 100, 186-191; SC 210, 47-48; Rousseau \& Doutreleau 1979:30ff.; Loofs 1890). ${ }^{3}$ The passage as a whole is a fairly literal (if not, clumsy) Latin rendering ${ }^{4}$ of the lost Greek text, and reads as follows:

Alii autem rursus Cain a superiore Principalitate dicunt, et Esau et Core et Sodomitas et omnes tales cognatos suos confitentur: et propter hoc a Factore impugnatos, neminem ex eis malum accepisse. Sophia enim illud quod proprium ex ea erat abripiebat ex eis ad semetipsam. Et haec Iudam proditorem diligenter cognouisse dicunt, et solum prae ceteris cognoscentem ueritatem, perfecisse proditionis mysterium: per quem et terrena et caelestia omnia dissoluta dicunt. Et confi(n)ctionem adferunt huiusmodi, Iudae Euangelium illud uocantes. [And others again declare (that) Cain (was) from the superior Principle, and they confess that Esau and Korah and the Sodomites and all such people are their cognates: and for this reason attacked

1.Tales quidem secundum eos sententiae sunt: a quibus, uelut Lernaea hydra, multiplex capitibus fera [de] Valentiniani scola generata est ...' (Rousseau \& Doutreleau 1979:384).

2.Cf. the parallel introduction of the Ophites (as they were called in later tradition) in Adv. Haer. I, 30, 1: 'Alii autem ...' (Rousseau \& Doutreleau 1979:364)

3.Oftentimes in recent discussions, the complex question of the chapter headings has not been taken into account, with the result that some scholars maintain on the basis of Irenaeus's testimony (or rather, on the basis of chapter headings that were later added) that the Gospel of Judas stems from the so-called Cainites. Similarly others would erroneously argue that Irenaeus was wrong in this respect. These scholars fail to acknowledge that, strictly speaking, Irenaeus himself utters not a word of the 'Cainites' in the 'paragraph' respect. These scholars fail to acknowledge that, strictly speaking, Irenaeus himself utters not a word of the 'Cainites' in the 'paragraph'
pertaining to the Gospel of Judas. Rather, the link between this text and the Cainite Gnostics is to be found in later testimonies (or may be inferred from them; see below).

4.In all likelihood, the translation stems from a person who had little command of Latin, but an excellent mastery of Greek. See for example Doutreleau's remarks - crucial parts of which are based upon the studies of S. Lundström - in the various Sources Chrétiennesvolumes. The literal translation can, more often than not, be retransferred into Greek rather effortlessly, which fully warrants our current use of the Latin translation as a basis for our analysis. 
by the Creator, none of them has suffered harm. For Sophia snatched away that which belonged to her out of them to herself. And Judas, the betrayer, they say, had got a thorough knowledge of these things; and he alone, knowing the truth above all the others, accomplished the mystery of the betrayal. Through him all things, both earthly and heavenly, have been dissolved, as they say. And they adduce a composed work to this effect, which they call 'the Gospel of Judas.] (Adv. Haer. I, 31, 1; Rousseau \& Doutreleau 1979:386, [The English translation has been kept as literal as possible])

As a first step towards a better understanding of the passage, some words and phrases will briefly be annotated. Former English translations of Irenaeus's text will not be ignored in these annotations, especially not the ones that have recently been published in books and other studies on the Gospel of Judas (Wurst 2006:121-135, 2008:169-179; Ehrman 2006; Pagels \& King 2007; Gathercole 2007; DeConick 2007; Turner 2008:190-191; DeConick 2011; see also Roberts \& Donaldson [1885] 1979:358; Foerster \& Wilson 1972:41-42; Layton 1987:181; Unger 1992:102-103). ${ }^{5}$ Moreover, particular attention will be devoted to other patristic testimonies about the Gospel of Judas: these will include, firstly, the Greek testimony of Epiphanius, the bishop of Cyprus, who wrote his Panarion 38, commonly known as the Refutation of all heresies, in circa 375; and, secondly, the Greek testimony of Theodoret, bishop of Cyrrhus in Syria, who composed his Haereticorum Fabularum Compendium (Compendium of Heretical Fables) at some stage during the middle of the 5th century. Of particular interest is Haereticorum Fabularum Compendium I, 15. It is generally assumed that Epiphanius's testimony is dependent upon Irenaeus and, probably, a second written source, whilst Theodoret, in his brief paragraph on the 'Cainites', appears to be handing down an abstract of Irenaeus's passage, based on its original Greek wording. We now continue with an annotation of the text quoted above.

a superiore Principalitate ...: [from the superior Principle ...]: This 'Principle', being the supreme Authority above all

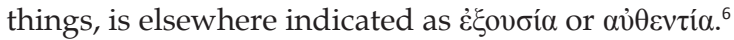

Recent English discussions of the passage have tended to translate principalitas with 'power' (cf. e.g. Wurst 2006:123, 2008:170; Gathercole 2007:116; DeConick 2007:17; Turner 2008:190). When it comes to Irenaeus's accounts of Gnostic systems, however, the noun 'power' should rather be reserved for translating uirtus (cf. Adv. Haer. I, 30, 1ff. or I, 26,

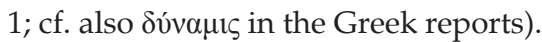

propter hoc ...: [for this reason ...]: In other words, for being a superiore Principalitate.

Sophia enim illud quod proprium ex ea erat abripiebat ex eis ad semetipsam: for Sophia snatched away that which belonged to her out of them to herself. Strictly speaking, one may also translate the imperfect abripiebat with the phrase 'was in the

5. In contrast to its German original, the English translation in R. Haardt (1971:65-66) is of little value.

6.See the presumed original Greek text of Irenaeus that was reconstructed on the basis of Theodoret (Haer. fab. I, 15; Rousseau \& Doutreleau 1979:312). See also, for example, Principalitas in Irenaeus's account of Cerinthus (Adv. Haer. I, 26, 1

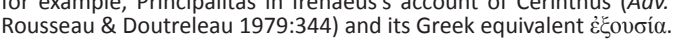

habit of snatching away' (cf. Theodoret's aorist $\alpha v \eta \dot{\rho} \rho \alpha \sigma \varepsilon v)$. Moreover, illud quod proprium ex ea erat may literally be translated as 'that which was her own from herself' or 'that which was her own (and came) out of her.' Correspondingly, Theodoret (Haer. fab. I, 15) transmits: 'For Sophia snatched away that which was her own in them out of them': $\dot{\eta} \gamma \grave{\alpha} \rho$

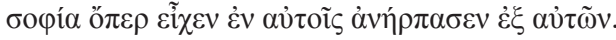

Iudam proditorem ...: [Judas, the betrayer ...]: See below the annotation on proditionis mysterium: 'the mystery of the betrayal.'

haec ...: [these things] ... Haec refers to that which immediately precedes it, namely (an essential part of) the myth of Sophia. With reference to the use of haec in this context, Layton (1987:181) notes: 'Perhaps referring to the union of the anointed (Christ) and Jesus as related in 1.30.12-13.' Although this view is interesting and has the advantage of relating haec to an essential part of the Gospel's core message, it is highly problematic considering the standard use of this Latin pronoun.

solum prae ceteris cognoscentem ueritatem ...: [he alone knowing the truth above all the others ...]: 'Above' or 'better than the others' refers to the other disciples or apostles, as

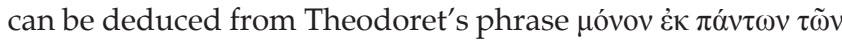

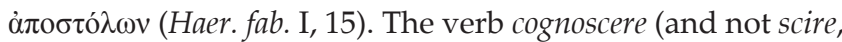
for example) yet again refers to a process: 'having become

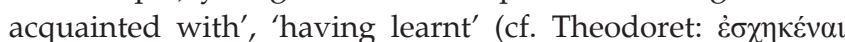
$\tau \eta \dot{v} \gamma \nu \tilde{\omega} \sigma i v)$. The subject of this initiation process is 'the truth' or the gnosis, as Theodoret aptly calls it. The content of 'the truth' is that of (the essence of) the myth of Sophia.

proditionis mysterium ...: [the mystery of the betrayal ...]: It is not clear from Irenaeus's text whether proditio has any negative connotation in the context of the phrase perfecisse proditionis mysterium (cf. the New Testament's $\pi \alpha \rho \alpha \delta i \delta o v \alpha 1)$.

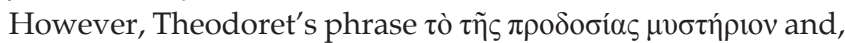

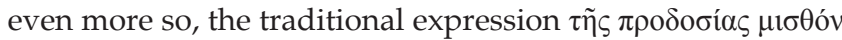

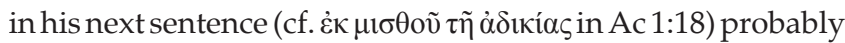
rule out the possibility that proditio bears any positive or neutral connotations in this context. These phrases rather seem to suggest that the concurrent designation of Judas's deed with $\pi \rho \circ \delta$ ofía (proditio, [betrayal]) had been adopted here. It might even be likely that the Gnostics themselves already had this designation in mind. In the current context, however, this traditionally negative meaning of proditio/ $\pi \rho o \delta$ ofí $\alpha$ is now (reversely) re-evaluated in a very positive way (and thus fully coincides with the positive meaning of mysterium).

per quem ...: [through him ...]: The Latin per quem refers to Judas and not to the preceding mysterium. If the latter were the case, the Latin would have read 'per quod', which is not an option given from any of the manuscripts collated by Rousseau and Doutreleau (1979), Harvey (1857), Stieren (1848-1853) or Massuet ([1710] 1857). This does not imply, however, that the translation 'by which' is utterly invalid 
(cf. e.g. Foerster \& Wilson 1972:42). In this literary context, the phrase 'by/through him' seems to imply: 'through his deed.' 'Deed' here refers to the deed of the one who did get knowledge of (and hence knows) the truth.

dissoluta ...: [dissolved ...]: Curiously, most of the English renditions consulted translate dissoluta with either 'thrown into confusion' (e.g. Roberts \& Donaldson 1885:358; cf. Pagels \& King 2007:xii; DeConick 2007:174; Turner 2008:191) or 'thrown into dissolution' (e.g. Layton 1987:181; cf. Wurst 2006:123, 2008:170). As far as I'm concerned, there is absolutely no reason to introduce the concept of 'confusion' into the text. The same goes for the verb 'throw', if taken literally. Irenaeus's text has 'dissolved' (so rightly Foerster \& Wilson 1972:42; cf. Gathercole 2007:116). The verb dissoluere may also be translated with 'destroy' (Unger 1992:103; followed by Ehrman 2006:63): the original Greek probably

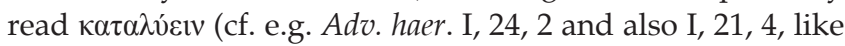
so many passages in the New Testament; see also below for a further discussion on the verb dissoluere).

confi(n)ctionem ...: [a composed work ...]: From existing editions (see in particular the apparatus criticus in Rousseau \& Doutreleau 1979:386), it is clear that only Erasmus reads 'confinctionem' (in his editio princeps of 1526). The principal manuscripts, including C (= Claromontanus from the 9th $c$.) and V (= Vossianus from the year 1494), read 'confictionem'. Moreover, the manuscript A (= Arundelianus, 12th $c$.) reads 'confinetionem' and the manuscript $Q$ (= Vaticanus, $c$. 1429) reads 'confinectionem'. On the possible implications of these variae lectiones, see below. As a matter of fact, the Latin word confi(n)ctio can be translated with 'fabrication', 'invention', or even 'fiction'. Presently consulted English renditions variously translate confi(n)ctio with 'a fictitious history' (Roberts \& Donaldson [1885] 1979:358; Pagels \& King 2007:xii; DeConick 2007:174), 'a fabrication' (Foerster \& Wilson 1972:42), 'a fabricated work' (Layton 1987:181; Wurst 2006:123, 2008:170; Turner 2008:191), 'a fabricated book' (Gathercole 2007:116) and even 'fiction' (Unger 1992:103; Ehrman 2006:63) or 'second-rate work' (Haardt 1971:65). Rousseau and Doutreleau (1979:387) steer a middle course: 'un écrit de leur fabrication'. Despite all these renderings, it is very doubtful that the word confinctio (cf. Harvey 1957) or confictio (the most likely reading, rightly followed by Massuet [\{1710\} 1857] and Stieren [1848-1853]; cf. above on the MSS) has a principally negative connotation in this literary context (Van Oort 2009b). Truth be told, the Thesaurvs Lingvae Latinae (henceforth: TLL) (vol. IV:205 s.v. 'confictio') does indeed propose the negative dolosa excogitatio as one of the possible meaning variants of confictio. Nonetheless, other meaning variants are also given, including formatio. The positive meaning of the latter word can easily be illustrated by a quote from the Collectio Avellena: qui ... plasmatus est et

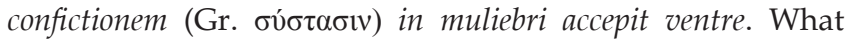
is more, the noun derives from confingere, its equivalent, according to glossaria, being $\sigma 0 ́ v \theta \varepsilon \sigma 1 \varsigma, \sigma v ́ \mu \pi \lambda \alpha \sigma 1 \varsigma$ (cf. Loewe [1888] 1965:442, 446). What more can be said of the word confingere? The TLL (vol. IV:213-214 s.v. confingere) begins by indicating that the verb is composed of con and fingere.
The first meaning of the verb is fingendo efficere comminisci. From its many testimonies, it would certainly appear that fingendo efficere comminisci is the preponderant meaning of confingere. Its second meaning is componere, conficere, which also has a considerable number of testimonies. As such, componere, conficere should also be seen as a central and wellattested meaning of confingere. The testimonies of the second category include examples from Varro ${ }^{7}$ and Pliny 'the Elder' ${ }^{8}$ In my opinion, the person who once ${ }^{9}$ translated Irenaeus's original Greek into Latin, mainly had this second (largely literal, elementary and basic) meaning in view. The most likely literal meaning of 'con-fictio' is therefore 'com-posite'. The latter could be defined as a work that has been conflated from several components. Evidence to support this claim is primarily found in Epiphanius. In his report of the Gospel of Judas and the Gnostics who adduce ( $\varphi \varepsilon ́ p \varepsilon v v)$ it, he terms it a

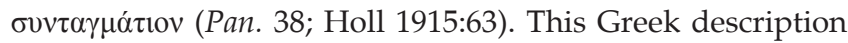
seems to indicate a (small) work that has been put together from several components. Although it is impossible to deduce from the Latin translation of Irenaeus's testimony that this writing was small, the suggestion thereof, proffered by the word con-fictio, is supported by Epiphanius's $\sigma v v-\tau \alpha \gamma \mu \alpha$ ó 1 ov. It is quite possible that Irenaeus used this word in his original Greek text (cf. Reynders 1954:62). Another possibility is offered by the parallel text Adversus Haereses I, 20, 1 (see below). From that text, one may deduce that Irenaeus's original Greek read something like $\sigma 0 ́ \mu \pi \lambda \alpha \sigma ı \varsigma^{10}$ The latter indicates in the first place, a writing moulded or fashioned together. It is only in a secondary and transferred sense that $\sigma \dot{0} \mu \pi \lambda \alpha \sigma i \varsigma$ could also then connote the predominantly negative overtones of 'fabrication' or the completely negative meaning of 'fiction' or 'feigned work'. It is important to note that with regard to the writings of the Marcosians - which he mentions as one of his sources of information - Irenaeus also speaks of writings that 'they adduce' and 'have composed/fabricated'. Adversus Haereses I, 20, 1 is particularly telling in this context: super haec autem inenarrabilem multitudinem apocryphorum et perperum scripturarum, quas ipsi finxerunt, adferunt ... (Rousseau \& Doutreleau 1979:288). Significantly, the latter is markedly

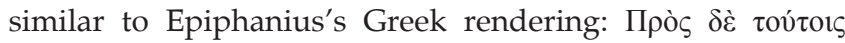

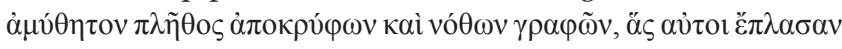
$\pi \alpha \rho \alpha \varphi \varepsilon ́ p o v \sigma i v$... Finally, Theodoret of Cyrrhus appears to corroborate this meaning of confictio. In his Haereticorum fabularum compendium I, 15, he hands down an abstract from Irenaeus's original Greek passage on the Gospel of Judas and their Gnostics. Referring to the Gospel, he emphatically

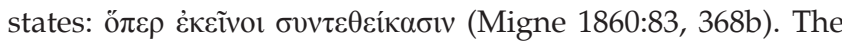

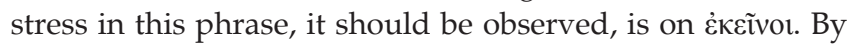
using this word, Theodoret is explaining to his readers that Judas did not write the Gospel named after him, but that it

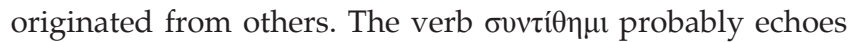

7.Ling. 5, 7: 'quemadmodum quodque poeta finxerit verba, [quod] confinxerit, [quod] declinarit.'

8.Nat. 10, 91: 'nec unde confingantur (halcyonum nidi), invenitur'; 10, 93: 'eadem materia confingunt nides'; et cetera.

9.For an overview of discussions about the dating of the translation, see Doutreleau's remarks in the various volumes of his edition of Irenaeus's Adv. haer. Also see, in particular Lundström $(1943,1948)$

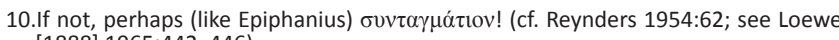
[1888] 1965:442, 446). 
Irenaeus's original Greek noun, transmitted by the Latin translator as confictio. As a matter of fact, the word confictio, like its suggested equivalent $\sigma 0 ́ \mu \pi \lambda \alpha \sigma ı \varsigma$ (see e.g. Liddell \& Scott 1973:1683-164), does have the negative connotation of 'feigned' or 'fabricated'. But this connotation is not inherent to the meaning of $\sigma v ́ v \tau \alpha \gamma \mu \alpha$, which can be translated with 'that which is put together in order' and 'treatise, work, book' (Liddell \& Scott 1973:1724). Neither is it inherent to the

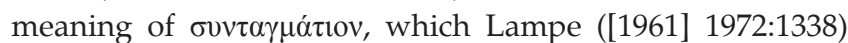
defines as the 'diminutive of $\sigma 0 ́ v \tau \alpha \gamma \mu \alpha$, little treatise, little work.' Not even $\sigma 0 v v \theta \varepsilon \sigma 1 \varsigma$ carries the negative connotation and can be translated with 'putting together, composition, combination' (Liddell \& Scott 1973:1716; cf. Lampe [1961] 1972:1328-29). The Latin translator made an appropriate choice when opting for an ambiguous word such as confictio to convey Irenaeus's description of the peculiar Gospel of Judas. His readers are in danger, however, of misconstruing the original meaning of the word and, as a result, overlooking one of the cardinal characteristics Irenaeus intended to transmit about the Gospel. If adequate attention is paid to the course of Irenaeus's exposition in Adversus Haereses, it becomes abundantly clear that he deals in Adversus haereses I, 31 with a group of Gnostics (later referred to as 'Cainites' by Epiphanius and Theodoret, among others), whose teachings are based on doctrines operative in other Gnostic groups. Already from Irenaeus's testimony, it is possible to deduce that the Gospel of Judas was a composite text, even though the word confictio simultaneously bears the negative connotation of something that has been put together. But Irenaeus (and the same goes, in his wake, for Epiphanius and Theodoret) does not term it a mere fabrication or fiction. From the newly discovered Gospel of Judas, we learn that the information provided by Irenaeus is correct. The Gospel of Judas is a work composed of several Gnostic (mainly 'Sethian') traditions, as well as from other traditions (see Scopello 2008). ${ }^{11}$

adferunt ...: [adduce ...]: Adferunt has several meanings (so rightly Wurst 2006:127, 2008:172) and can be translated by 'they bring forth', 'they adduce', 'they produce', 'they put forward', 'they present', et cetera (cf. Pan. 38, 1, 5; Holl

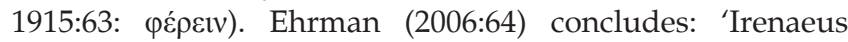
never says that the Gospel of Judas was actualluy written by the Cainites, only that they used it.' In my view, however, the use of the verb adferre (or pép\&ıv) in no way excludes the possibility that this Gospel was their own product. In fact, three indications point to exactly this conclusion. Firstly, one may compare Irenaeus's reference to the writings of the Marcosians and their $\pi \alpha \rho \alpha \varphi \varepsilon ́ p \varepsilon ı v$ in the preceding annotation. Secondly, a close reading of Irenaeus's subsequent remark about the (other) writings of the Gnostics he is dealing with probably indicates that they composed it themselves (see below). Thirdly, we have the testimony of Theodoret, who may be considered to have handed down Irenaeus's lost Greek text nearly verbatim. Theodoret explicitly says:

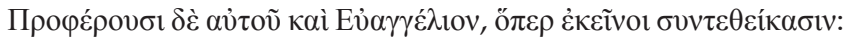

11.The major part of the essays included in this volume refer to 'Sethian' elements, some (e.g. Dubois 2008:145-154) to 'Basilidean' elements, others to the apparent 'biblical' traditions. As it is generally assumed (and becomes evident at first reading), the main contents of the Gospel of Judas as we now have it in a Coptic version consists of '(pseudo-) historical' information on the one hand and highly interesting Gnostic (mainly 'mythical') information on the other.
[And they also/even bring forth a Gospel of him [sc. Judas], which they themselves have composed.]

Before elaborating any further on Irenaeus's rather brief (but essential) passage, I would like to quote the line immediately thereafter. Here, Irenaeus states: Iam autem et collegi eorum conscriptiones(,) in quibus dissoluere opera Hysterae adhortantur: Hysteran autem Fabricatorem caeli et terrae uocant [And, ${ }^{12}$ further, I have also made a collection of their writings, ${ }^{13,14}$ in which they exhort to dissolve the works of the Hystera \{womb\}: Hystera they call the Creator of heaven and earth'] (Adv. Haer. I, 31, 2; Rousseau \& Doutreleau 1979:386).

This sentence is reasonably clear about an issue of prime interest within the current context. Irenaeus explicitly states that he made a collection of the (primary) writings of the Gnostic sect he is dealing with. What is implied by this statement is less clear, however. As already indicated by my translation, the Latin $i a m^{15}$ appears to make a connection between this sentence and the preceding lines: 'Further/ Moreover, I have also made a collection of their (other) ${ }^{16}$ writings.' Two conclusions can be inferred from this explicit statement, namely that Irenaeus himself ${ }^{17}$ succeeded in collecting the texts mentioned and that the information provided by Irenaeus stems from these books. In their books, the relevant Gnostics 'exhort to dissolve the works of the Hystera', in other words, the works of 'the Creator of heaven and earth'.

Recent publications discussing Irenaeus's testimony of the Gospel of Judas detect an antithesis between the sentence just quoted and the passage that precedes it (cf. e.g. Wurst 2006:127-128, 2008:173-174; Gathercole 2007:119). Accordingly, or so it is argued, Irenaeus fails to indicate any first-hand knowledge of the Gospel of Judas (cf. Wurst 2012:1222). His reference to personally collecting some Gnostic writings seems to be in sharp contrast with the preceding lines. In keeping with this line of argument, the only viable conclusion is that - in all probability - Irenaeus did not have any direct knowledge of the Gospel of Judas.

12. Here and in the previous Latin quotation, we may render autem either by 'and' or 'but' or leave it untranslated. Autem here and elsewhere in Irenaeus apparently seems to render the original Greek $\delta \varepsilon$

13.Or, perhaps, 'compositions' as well? With the Latin word conscriptiones, however Irenaeus seems to denote writings in general (cf. e.g. Adv. Haer. I, 25, 5; Rousseau \& Doutreleau 1979:342).

14.It is interesting to speculate about the comma here. As far as I can tell and based on the editions available to me, the said punctuation mark seems (or better, in view of its likely absence in the mss, is supposed) to be necessary. Theodoret does

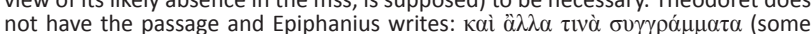

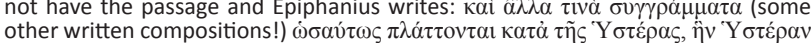

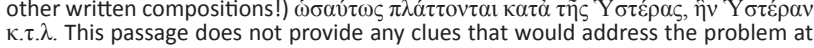
$\kappa . \tau . \lambda$. This passage does not provide any clues that would address the problem at
hand. However, if the comma is supposed to be absent, Irenaeus states that he has collected other writings of these Gnostics where they also speak of (the theme of) dissoluere.

15.See the use of iam in widely-read (and imitated) writers like Cicero and Vergil, who not only use the word to denote 'already', but also 'moreover' or 'indeed'.

16.Although 'other' is not literally present in the text by means of, for instance, the adjective aliae, a translation like the one given here is quite naturally justified by the context (and perhaps, also by the rather emphatic et). Cf. the French translation in Rousseau and Doutreleau (1979:387): 'J'ai pu rassembler d'autres écrits émanant d'eux.'

17.Cf. below the discussion on the possible sources from which the passage might have been taken, which leads to the inevitable conclusion that Irenaus had firsthand knowledge of such writings. 
Such a conclusion is doubtful. If the report is read as it stands, without it having been influenced by an anachronistic subdivision of the text (cf. Rousseau \& Doutreleau 1979:386; Roberts \& Donaldson [1885] 1979:358; Foerster \& Wilson 1972:42), an entirely different conclusion turns out to be much more likely. ${ }^{18}$ Irenaeus makes mention of the Gospel of Judas and, immediately thereafter, states that he has even made a collection of the (other) writings of the Gnostics who 'adduced' it. The first and, apparently, main characteristic of these writings is that they exhort to dissolve the works of the Creator. ${ }^{19}$ This activity of dissoluere is also described as a central tenet of the Gospel of Judas: 'through him (= Judas) all things, both earthly and heavenly, have been dissolved.'

Hence, the word dissoluere ${ }^{20}$ seems to signify an essential relation between the contents of various Gnostic writings. Irenaeus is clearly of the opinion that a number of writings, not least of all the Gospel of Judas, stem from one and the same Gnostic group. The close relation between these writings is revealed most prominently by the fact that similar concepts are central to all of them. Such concepts include not only Hystera and dissoluere, but also Factor and Fabricator, as well as diligenter cognouisse and scientia perfecta, among others. Such closely related subject matters oblige the unavoidable conclusion that these writings are intimately linked.

This brings us to the obvious follow-up question: Did Irenaeus personally read these texts? Few doubt the probability that Irenaeus actually read the writings he so emphatically said to have collected. It is fairly safe to assume that a person who not only intentionally collects certain texts, but is also able to communicate central tenets from their contents, would have read those texts.

But does the same hold true for the Gospel of Judas? I can think of no compelling or feasible reasons for doubting this either. When conveying the contents of various 'Valentinians' and other Gnostics, the writings of whom Irenaeus also explicitly claims to have had access to, he uses the same communicatory procedures as in Adversus Haereses I, $31 .{ }^{21}$ In his discussion of the Gnostics represented by the Gospel of Judas, Irenaeus discloses and betrays a familiarity with some of their core doctrines. He also repeatedly and with a fair bit of emphasis

18.In many recent references to and discussions of Irenaeus's testimony (e.g. Ehrman 2006; Pagels \& King 2007; DeConick 2007), this sentence is not mentioned at all. It is also conspicuously absent in Layton (1987:181).

19.The remainder of Irenaeus's notice is nothing else than a further explication of this principal duty to which the writings exhort: Nec enim aliter saluare eos nisi per omnia eant, quemadmodum et Carpocrates dixit. Et in unoquoque peccatorum per omnia eant, quemadmodum et Carpocrates dixit. Et in unoquoque peccatorum et turpium operationum Angelum adsistere, et operantem audere audaciam et immunditiam inferre, id quod inest ei operationi, Angeli nomine dicere: $\mathrm{O}$ tu, esse scientiam perfectam, sine timore in tales abire operationes, quas ne nominare quidem fas est (Adv. haer. 1,31,2; Rousseau \& Doutreleau 1979:386)

20.Which has a remarkable parallel in the Gospel of Mary (BG 8502, 15, 20-16, 1): ‘ have recognized that the All is being dissolved, both the earthly (things) and the heavenly things' (cf. Tuckett 2007:94-97).

21.(a) Adv. haer. I, praef. 2: cum legerim commentarios ipsorum ... Valentin discipulorum; (b) Adv. haer. I, 20, 1 with regard to the 'Marcosians' (after having iven samples from their ' given samples from their 'exegesis', obviously from their own writings as well): super haec autem inenarrabilem multitudinem apocryphorum et perperum scripturarum, quas ipsi finxerunt, adferunt ...; (c) Adv. haer. 1, 25, 4 with regard to the followers of Carpocrates: secundum quod scripta eorum dicunt; (d) cf. Adv. Haer. 1,25,5: In conscriptionibus autem illorum sic conscriptum est et ipsi ito exponent (Rousseau \& Doutreleau 1979:22, 228, 338, 342). uses the words dicunt [they declare, they say, as they say] and uocant [they call], as opposed to, say, dicuntur [they are said .... Irenaeus tends to make use of the latter word when he wishes to indicate that he is dealing with some sort of second-hand story (cf. e.g. dicitur in Adv. haer. I, 23, 1). Time and again, both these features (of using the words dicunt or uocant and of transmitting core doctrinal contents) are to be found in comparable literary contexts where Irenaeus's first-hand knowledge of the relevant Gnostic group and its doctrines are beyond doubt. It may currently suffice to refer to the very first sentence of Irenaeus's first report in his Against Heresies: 'Dicunt esse quendam in inuisibilibus et inenarrabilibus altitudinibus perfectum Aeonem, qui ante fuit; hunc autem et Proarchen et Propatora et Bython uocant' (Adv. haer. I, 1, 1; Rousseau \& Doutreleau 1979:28). Further proof could easily be gained from glancing at the ensuing first-hand reports (Adv. haer. I, 1, 2ff.) of other Valentinians (Adv. haer. I, 11-12, esp. 12, 1ff.), the Gnostic Marcus and the Marcosians (Adv. haer. I, 13ff.), and the followers of Carpocrates, amongst others (Adv. haer. I, 25ff., esp. I, 25, 4) (cf. Rousseau \& Doutreleau 1979:32ff., 180 ff., 188ff., 338f.).

If measured according to our standards (and eagerness to know), Irenaeus's information about the tenets of the Gnostic group under discussion and about their view of Judas might seem somewhat brief. However, if it is recognised that his description of the relevant Gnostics occurs within the context of an appendix to his overview of the 'Valentinians's' ascendants, one cannot help but conclude that his remarks are not noticeably brief or conspicuously vague at all. In fact, they appear to be rather detailed.

Before continuing with the present discussion of our topic, we first need to halt at a vexing and (still) much disputed issue. Oftentimes in previous research, it has been claimed that Irenaeus is dependent on a non-Gnostic source for his overview of the ascendants of 'the Valentinian school' (Adv. Haer. I, 23-30/31) or for his description of the ancient and more remote ancestors of the 'Valentinians' (Adv. Haer. I, 23-28). Supposedly, this derived source is the (unfortunately lost) Syntagma of Justin Martyr (Apol. 1, 26, 8; Lipsius 1865), or some updated version of this heresiological work (Lipsius 1875; cf. Hilgenfeld [1884] 1963:46-58). ${ }^{22}$ It is indeed possible to discern a marked difference between the long sections in Adversus Haereses I, 1-21 and the shorter section in Adversus Haereses I, 23-28. In the former, Irenaeus purports to have held written works of the Gnostics he is refuting, not to mention his personal contacts with them. In the latter, he very briefly discusses their (obviously) more remote ancestors. There seems to be enough reason for assigning the main contents of Adversus Haereses I, 23-28 to a derivative, unoriginal source, be it Justin's Syntagma or some reworked version of this

22.For a number of reasons, Hilgenfeld himself remained an adherent of Lipsius's original theory. As regards the Gospel of Judas and the possible sources of Irenaeus's report in 1, 31, 1-2, neither Lipsius nor Hilgenfeld provide any specific tauch underline Hilgenfeld's ([1875] 1963:49) passing remark that Irenaeus 'auch über die gnostischen Vorläufer der Valentinianer selbständige Forschungen angestellt hat $(1,31,2)$.' 
writing (see Wisse 1971:205-223, esp. 214-215). However, already with regard to Adversus Haereses I, 29-30 (on the socalled 'Barbelo-Gnostics' and the Gnostics termed 'Ophites' in later tradition), one may side with those who argue that Irenaeus, yet again, refers to sources that were contemporary to these Gnostics, writings he was personally acquainted with (Perkins 1976:193-200, esp. 197-200; cf. Hilgenfeld [1884] 1963, n.29). Such conclusions are based on Irenaeus's style and his rather detailed summary.

The very same impression is given by the section that immediately follows (Adv. Haer. I, 31, 1-2). ${ }^{23}$ In order to indicate, firstly, that they are also a branch of the multitudo Gnosticorum and, secondly, that they are similar to the previously described 'Barbelo-Gnostics' (I ,29, 1-4), Irenaeus introduces the 'Ophites' (I, 30, 1-14) as some other alii. In exactly the same manner, Irenaeus also introduces the Gnostics of the Gospel of Judas in Adversus Haereses I, 31, 1 as some other alii when he says: 'Others again declare ... and confess.' The exact content of what they 'declare' and 'confess' and 'say' and 'call' is then briefly outlined. He even includes what appears to be an explicit quote from one of 'their other writings' (cf. Adv. haer. I, 31, 2). ${ }^{24}$ Style and content are not the only reasons for doubting the utilisation of a derivative heresiological source. Another reason is the occurrence of the sentence: Iam autem et collegi eorum conscriptiones ['Moreover, I have also made a collection of their writings']. ${ }^{25}$ If it is assumed that he did copy from a heresiological source, then Irenaeus would turn out to be a very clumsy 'author'. Yet, there is more than enough evidence from Irenaeus's literary heritage of his rhetorical skill (see Perkins 1976:194-197; Reynders 1935:5-27; Schoedel 1959:22-32). Such skill would undoubtedly have prevented him from making such a blunder. Since Irenaeus was not a clumsy author, and since his first readers were very likely intelligent people, and lastly, since it is extremely difficult to accept that later manuscript writers would have been inattentive enough to overlook this sentence, ${ }^{26}$ it may be concluded with a fair amount of certainty that the combined evidence points only in one direction: Irenaeus intended to communicate to his audience that he personally collected and read the writings he then goes on to discuss and even quote. There also seems to be no reason for reaching any other conclusion concerning the Gospel of Judas: Irenaeus not only would have had first-hand knowledge of its existence and content, but he also appears to have read the text.

23.Or, perhaps more precise: Adv haer. I, 30, 15-31, 2. Cf. both the division and the heading 'Sectes apparentées' preceding the French translation of this section in Rousseau and Doutreleau (1979:384-387). One might also suppose, however, that in Adv. haer. I, 30, 15 Irenaeus is speaking of a subgroup of the 'Ophites' (cf. Scholten 2001:972).

24. Rousseau and Doutreleau (1979:386): O tu, Angele, abutor opere tuo; o tu, illa Potestas, perficio tuam operationem.

25.The sentence did not fit (part of) Wisse's theory about Irenaeus's sources and therefore, in a footnote, he curiously remarks: 'Since Irenaeus in the preface to Adv. haer. I refers only to the "commentaries" of the disciples of Valentinus, the Adv. haer. I refers only to the "commentaries" of the disciples of Valentinus, the
first person singular in I, 31, 1 must have been copied from his source' (Wisse 1971:215, n. 44).

26.None of the current editions indicate a different reading (cf. Stieren 1848-1853; Harvey 1857; Rousseau \& Doutreleau 1979).
On the basis of these remarks, the most important particulars transmitted by Irenaeus may be summarised as follows:

- there is a Gospel of Judas

- this Gospel is linked to certain Gnostics, who considered themselves to be ascendants of the (positively-evaluated) Old-Testament figure Cain (and persons related to him)

- these Gnostics had knowledge of a superior Principle and spoke about the Creator in a negative way

- they told of Sophia and her activity

- Judas was believed to be well acquainted with (parts of) a myth in which Sophia is seen as a redeemer figure

- it was for this reason that Judas was characterised as 'knowing the truth', in other words, as a real Gnostic, in contrast to 'the others' (i.e. the other apostles)

- because of this knowledge, Judas 'accomplished the mystery of the betrayal'

- 'through him', that is, because of his deed of 'betrayal', 'all things, both earthly and heavenly, have been dissolved'

- a special group of Gnostics (called 'Cainites' in later tradition) developed a writing to this effect, which they named 'the Gospel of Judas'

- this writing is explicitly referred to as 'a composed work'.

An essential crux of Irenaeus's report is the word huiusmodi that appears near the end of the passage: 'Et confi(n)ctionem adferunt huiusmodi, Iudae Euangelium illud uocantes.' I translated the sentence as follows: 'And they adduce a composed work to this effect, which they call "the Gospel of Judas".' One may also translate: a composed work 'of that kind' or 'of/in that manner'. The question is: Does the word huiusmodi, being a further specification of the Gospel's contents, indicate that it only dealt with Judas, his particular gnosis, his 'betrayal', and its cosmic effects? Or does huiusmodi also refer to a comprehensive mythological story of which Irenaeus presents an outline? On the basis of the preceding word haec (Et haec Iudam proditorem diligenter cognouisse dicunt: [And they say that Judas the betrayer was thoroughly acquainted with these things]), I deem the latter possibility to be the most likely one (see above, the annotation to: 'haec .... these things ...'). Hence, according to Irenaeus, the Gospel of Judas did not only talk about Judas, his gnosis, his performance of the betrayal-mystery (which was based on that gnosis), and its earthly and heavenly consequences. It also contained a myth in which, either explicitly or (at least) implicitly, Sophia (and her redeeming activity), the bad Creator and the superior Principle each had a significant role.

Based on our former discussion of the word haec, which word refers primarily to Sophia and her activity, it is illegitimate to deduce from Irenaeus's passage with any degree of certainty that the Gospel of Judas spoke about Cain and other Old Testament figures like Esau, Korah and the Sodomites. Irenaeus simply suggests these particular Gnostics venerated the person of Judas in the same positive way they venerated Cain and the others. As happens to be the case with Judas, 'they confess' that 'all such people are their cognates.' In other words, Judas is of the same race as Cain and the other people. All of these persons are considered to be the real Gnostics.

A final remark concerns Irenaeus's designation of the Gospel of Judas as a confin(c)tio. As previously indicated Theodoret 


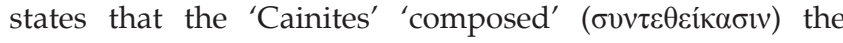

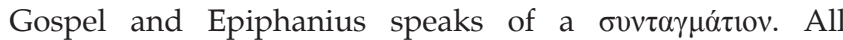
these designations seem to have a negative connotation. Nonetheless, they also seem to indicate genuine characteristics of the writing's literary structure. According to Epiphanius, it was a short work. Both Theodoret and Epiphanius appear to confirm Irenaeus's specification of the writing as a composition. Once again, if considered within the context of Irenaeus's testimony in Adversus Haereses, this feature seems to have important consequences. The Gnostics who not only 'adduced', but in actual fact also seem to have 'produced' the Gospel, apparently did so by putting together several (Gnostic) traditions. A hint to this conclusion may be Irenaeus's remark: quemadmodum et Carpocrates dixit (Adv. haer. I, 31, 2; Rousseau \& Doutreleau 1979:386), which not only seems to suggest that Irenaeus sees a parallel with the doctrines of the previously discussed Carpocrates and his followers (Adv. haer. I, 25, 1-6), but might also indicate that the Gnostics under discussion were partly indebted to Carpocrates's teachings. If the Gospel of Judas is indeed a composite of several (Gnostic) traditions and, moreover, if Irenaeus (and also Epiphanius and Theodoret) speak of the very same Gospel of Judas that was recently discovered, ${ }^{27}$ a decidedly 'Sethian' interpretation of its contents would be inherently flawed. Although the myth transmitted by the newly-discovered text undoubtedly contains 'Sethian' characteristics, ${ }^{28}$ Irenaeus's testimony, if read in context, teaches us that the Gnostics of the Gospel of Judas are others (alii) than, for instance, the 'Barbelo-Gnostics', discussed earlier. The Gnostics represented by the Gospel of Judas - in later tradition unequivocally termed 'Cainites' - seem to have made use of 'Sethian' tenets. ${ }^{29}$ But much of their content and system - if their diverse doctrines ${ }^{30}$ may be indicated as such - convinced Irenaeus to discuss them in a separate section of his Adversus Haereses. ${ }^{31}$

\section{Acknowledgements Competing interests}

The author declares that he has no financial or personal relationship(s) which may have inappropriately influenced him in writing this article.

27.Recent discussions have expressed the notion that Irenaeus might have been speaking of another Gospel of Judas. For example, Wurst (2006:134, 2008:178) states: 'But if the Gospel of Judas published here is the one in Irenaeus ...'. See also Brankaer and Bethge (2007:257): 'Wenn man mit der Möglichkeit rechnet, das unsere Schrift ein gewachsener Text ist, könnte Irenäus allerdings eine frühere bzw. eine andere Version gekannt haben.' On the other hand, Gathercole (2007:119123) concludes: 'So there is, after all, a sporting chance that Irenaeus is referring to what is to all intents and purposes our Gospel of Judas.' Although the possibility that Irenaeus had a different Gospel of Judas in mind still does exist (see also $n$ 30 below), nothing thereof is suggested (let alone substantiated) by the texts of Irenaeus or the Gospel of Judas as we now have it.

28. Even though the name of Seth might, according to some readings, not even appear in the text. Maybe we should read '[Ath]eth' in stead of '[Se]th' (cf. Kasser \& Wurst 2007:223; Kasser, Meyer, Wurst with Ehrman 2008:47, n. 125). However, others still prefer the reading '[Se]th' (Brankaer \& Bethge 2007:278-279, 358ff.).

29.Cf. the conclusion of Scholten (2001:981): 'Man wird daher das vermutete System der $K$. als eine Parellelbildung zum Entwurf der modern so genannten Sethianer bezeichnen dürfen.'

30.See, for example, the accounts of pseudo-Tertullian (Adv. omnes haer. II, 5-6; Kroymann 1954:1404) and Epiphanius (Pan. 38, 3; Holl 1915:65-66). If these discussions were based upon or introductions of a Gospel of Judas, then there would undoubtedly have been one or more versions of the Gospel. It remains noteworthy, however, that in all these interpretations, Judas is always considered noteworthy, however,
in a very positive light.

31.This article is a thoroughly revised, updated and expanded version of Van Oort (2009a). My thanks go to my former and present Pretoria assistents Llewellyn Howes and Yolande Steenkamp for their kind help.

\section{References}

\section{Primary sources:}

Epiphanius: Panarion 38 [Pan. 38]

Holl, K. (ed.), 1915, 'Panarion 38', in Die Griechischen Christlichen Schriftsteller 25, pp. 62-71, J.C. Hinrichs, Leipzig.

Gospel of Judas

Brankaer, J. \& Bethge, H-G., 2007, Codex Tchacos: Texte und Analysen, Walter de Gruyter, Berlin/New York. (Texte und Untersuchungen zur Geschichte der altchristlichen Literatur, 161).

Jenott, L., 2011, The Gospel of Judas. Coptic Text, Translation, and Historical Interpretation of the 'Betrayer's Gospel', Mohr Siebeck, Tübingen. (Studien und Texte zu Antike und Christentum, 64).

Kasser, R. \& Wurst, G. (eds.), 2007, The Gospel of Judas together with the Letter of Peter to Philip, James, and a Book of Allogenes from Codex Tchacos, National Geographic, Washington. (Critical Edition)

Gospel of Mary

BG = Berolinensis Gnosticus 8502, see Tucket

Tuckett, C.M., 2007, The Gospel of Mary, Oxford University Press, Oxford. http:// dx.doi.org/10.1093/acprof:oso/9780199212132.001.0001

\section{Main sources:}

Irenaeus: Adversus haereses [Adv. haer.]

Harvey, W.W., 1857, Sancti Irenaei episcopi Lugdunensis Libros quinque adversus haereses, Typis academicis, Cambridge.

Massuet, R., [1710] 1857, Sancti Irenaei episcopi Lugdunensis Libros quinque adversus haereses, Migne Patrologia Graeca 7, Apud J-P. Migne editorem, Parisiis.

Rousseau, A. \& Doutreleau, L., 1979, Irenée de Lyon: Contre les héresies (Livre I, Tome I+ II), Sources Chrétiens 263-264, Cerf, Paris.

\section{Compared translations:}

Irenaeus: Adversus haereses [Adv. haer.]

DeConick, A.D., 2007, The Thirteenth Apostle: What the Gospel of Judas Really Says, Continuum, London/New York.

Ehrman, B.D., 2006, The Lost Gospel of Judas Iscariot: A New Look at Betrayer and Betrayed, Oxford University Press, Oxford.

Foerster, W. \& Wilson, R.M., 1972, Gnosis: A Selection of Gnostic Texts, vol. I: The Patristic Evidence, Clarendon Press, Oxford.

Haardt, R., 1971, Gnosis: Character and Testimony, transl. J.F. Hendry, Brill, Leiden.

Layton, B., 1987, The Gnostic Scriptures, Doubleday, New York.

Pagels, E. \& King, K., 2007, Reading Judas: The Gospel of Judas and the Shaping of Christianity, Viking, New York.

Roberts, A. \& Donaldson, J. (eds.), [1885] 1979, The Ante-Nicene Fathers I, Wm. B. Eerdmans Publishing, Grand Rapids.

Stieren, A., 1848-1853, Sancti Irenaei Episcopi Lugdunensis Opera quae supersunt omnia, I-II, T.O. Weigel, Leipzig.

Turner, J.D., 2008, 'The Place of the Gospel of Judas in Sethian Tradition', in M. Scopello (ed.), The Gospel of Judas in Context, pp. 187-237, Brill, Leiden/Boston. http://dx.doi.org/10.1163/ej.9789004167216.i-404.53

Unger, D.J., 1992, St. Irenaeus of Lyons against the Heresies, vol. I, rev. edn., J.J. Dillon, Paulist Press, New York/Mahwah.

Wurst, G., 2006, 'Irenaeus of Lyon and the Gospel of Judas', in R. Kasser, M. Meyer \& G. Wurst (transl.), The Gospel of Judas, pp. 121-135, (+ notes pp. 171-173), National Geographic, New York.

Wurst, G., 2008, 'Irenaeus of Lyon and the Gospel of Judas', in R. Kasser, M. Meyer \& G. Wurst (transl.), The Gospel of Judas, pp. 169-179 (+ notes pp. 193-195), National Geographic, New York.

Justin Martyr: First Apology [Apol.]

Goodspeed, E.J., 1914, Die ältesten Apologeten, VandenHoeck \& Ruprecht, Göttingen.

Pliny the Elder: Naturalis Historia [Nat.]

Rackham, H. \& Jones, W.H.S., 1967, Pliny, Natural History, 10 vols., William Heinemann, London \& Harvard University Press, Cambridge, MA. (The Loeb Classical Library).

Pseudo-Tertullian: Adversus omnes haereses [Adv. omnes haer.]

Kroymann, E. (ed.), 1954, 'Adversus Omnes Haereses', in Corpus Christianorum Series Latina 2, pp. 1401-1410, Brepols, Turnholtii.

Theodoret: Haereticorum fabularum compendium [Haer. fab.]

Migne, J-P. (ed.), 1860, Patrologiae cursus completus: Series Graeca, vol. 83, Ex typis catholicis Migne, in vico dicto Montrouge, Parisiis.

Varro: De Lingua Latina Libri [Ling.]

Kent, R.G., 1938, On the Latin Language, 2 vols., William Heinemann, London \& Harvard University Press, Cambridge, MA. (The Loeb Classical Library).

\section{Dictionaries:}

Lampe, G.W.H., [1961] 1972, A Patristic Greek Lexicon, Clarendon Press, Oxford.

Liddell, H.G. \& Scott, R. (eds.), 1973, A Greek-English Lexicon, Clarendon Press, Oxford.

Reynders, B., 1954, Lexique comparé du texte grec et des versions latine, arménienne et syriaque de I' 'Adversus Haereses' de saint Irénée, vol. II: Index des mots latins, Imprimerie Orientaliste L. Durbecq, Louvain.

Thesaurvs Lingvae Latinae (TLL), 1906-1909, editvs avctoritate et consilio academiarvm quinqve Germanicarvm Berolinensis Gottingensis Lipsiensis Monacensis Vindobonensis, vol. IV, In aedibus B.G. Tevbneri, Lipsiae. 


\section{Secondary sources:}

Brankaer, J. \& Bethge, H-G., 2007, Codex Tchacos: Texte und Analysen, Walter de Gruyter, Berlin/New York. (Texte und Untersuchungen zur Geschichte der altchristlichen Literatur, 161).

DeConick, A.D., 2007, The Thirteenth Apostle: What the Gospel of Judas Really Says, Continuum, London/New York.

DeConick, A.D. (ed.), 2009, The Judas Codex: Proceedings of the Internationa Congress on Codex Tchacos held at Rice University, Houston, Texas, March 13-16, 2008, Brill, Leiden/Boston. (Nag Hammadi and Manichaean Studies, 71).

DeConick, A.D., 2011, 'After the Gospel of Judas: Reassessing what we have known to be true about Cain and Judas', in J.A. van den Berg, A. Kotzé, T. Nicklas \& M. Scopello (eds.), In search of truth: Augustine, Manichaeism and other Gnosticism: Studies for Johannes van Oort at sixty, pp. 627-661, Brill, Leiden/Boston. (Nag Hammadi and Manichaean Studies, 74).

Dubois, J-D., 2008, 'L' Évangile de Judas et la tradition basilidienne', in M. Scopello (ed.), The Gospel of Judas in Context, pp. 145-154, Brill, Leiden/Boston.

Ehrman, B.D., 2006, The Lost Gospel of Judas Iscariot: A New Look at Betrayer and Betrayed, Oxford University Press, Oxford.

Foerster, W. \& Wilson, R.M., 1972, Gnosis: A Selection of Gnostic Texts, vol. I: The Patristic Evidence, Clarendon Press, Oxford.

Gathercole, S., 2007, The Gospel of Judas, Oxford University Press, Oxford PMCid:2662929

Haardt, R., 1971, Gnosis: Character and Testimony, transl. J.F. Hendry, Brill Leiden.

Hilgenfeld, A., [1884] 1963, Die Ketzergeschichte des Urchristentums urkundlich dargestellt, Olms, Hildesheim.

Jenott, L., 2011, The Gospel of Judas. Coptic Text, Translation, and Historical Interpretation of the 'Betrayer's Gospel', Mohr Siebeck, Tübingen. (Studien und Texte zu Antike und Christentum, 64).

Kasser, R., Meyer, M. \& Wurst, G. (transl.), 2006, The Gospel of Judas, National Geographic, New York.

Kasser, R., Meyer, M. \& Wurst, G. (eds.) with B.D. Ehrman, 2006, The Gospel of Judas, National Geographic, New York.

Kasser, R. \& Wurst, G. (eds.), 2007, The Gospel of Judas together with the Letter of Peter to Philip, James, and a Book of Allogenes from Codex Tchacos, National Geographic, Washington. (Critical Edition).

Layton, B., 1987, The Gnostic Scriptures, Doubleday, New York.

Lipsius, R.A., 1865, Zur Quellenkritik des Epiphanios, W. Braumüller, Wien.

Lipsius, R.A., 1875, Die Quellen der ältesten Kirchengeschichte neu untersucht, J.A. Barth, Leipzig.

Loewe, G., [1888] 1965, Corpvs Glossariorvm, vol. II: Glossae Latinograecae et Graecolatino, (edidervnt Georgivs Goetz \& Gottholdvs Gvndermann), In aedibus B.G. Tevbneri, Lipsiae.
Loofs, F., 1890, Die Handschriften der lateinischen Übersetzung des Irenäus und ihre Kapitelteilung, Hinrichs, Leipzig.

Lundström, S., 1943, Studien zur lateinischen Irenäusübersetzung, Gleerup, Lund.

Lundström, S., 1948, Neue Studien zur lateinischen Irenäusübersetzung, Gleerup, Lund.

Pagels, E. \& King, K., 2007, Reading Judas: The Gospel of Judas and the Shaping of Christianity, Viking, New York.

Perkins, P., 1976, 'Ireneus and the Gnostics: Rhetoric and Composition in Adverus Haereses Book One', Vigiliae Christianae 30, 193-200.

Reynders, B., 1935, 'La polémique de saint Irénée: Methode et principes', Revue de Théologie Vigiliae Christianae 7, 5-27.

Schoedel, W.R., 1959, 'Philosophy and Rhetoric in the Adversus Haereses of Irenaeus', Vigiliae Chirstianae 13, 22-32. http://dx.doi.org/10.1163/157007259X00031

Scholten, C., 2001, s.v. 'Kainiten', in E. Dassmann (Hrsg.), Reallexikon für Antike und Christentum, 19, Dölger-Institut, Bonn, pp. 972-982.

Scopello, M. (ed.), 2008, 'The Gospel of Judas in Context', Proceedings of the First International Conference on the Gospel of Judas, Sorbonne, Paris, October 27-28, Brill, Leiden/Boston. (Nag Hammadi and Manichaean Studies, 62). http://dx.doi. org/10.1163/ej.9789004167216.i-404

Scopello, M., 2011, 'Motifs et expressions mystiques dans l'Evangile de Judas', in J.A. van den Berg, A. Kotzé, T. Nicklas \& M. Scopello (eds.), In search of truth: Augustine, Manichaeism and other Gnosticism: Studies for Johannes van Oort at sixty, pp. 593-609, Brill, Leiden/Boston. (Nag Hammadi and Manichaean Studies, 74).

Turner, J.D., 2008, 'The Place of the Gospel of Judas in Sethian Tradition', in M Scopello (ed.), The Gospel of Judas in Context, pp. 187-237, Brill, Leiden/Boston. http://dx.doi.org/10.1163/ej.9789004167216.i-404.53

Unger, D.J., 1992, St. Irenaeus of Lyons against the Heresies, vol. I, rev. edn., J.J. Dillon, Paulist Press, New York/Mahwah.

Van Oort, J., 2009a, 'Irenaeus on the Gospel of Judas: An Analysis of the Evidence in Context', in A.D. DeConick (ed.), The Judas Codex: Proceedings of the Internationa Congress on Codex Tchacos held at Rice University, Houston, Texas, March 13-16, 2008, pp. 43-56, Brill, Leiden/Boston.

Van Oort, J., 2009b, 'The Gospel of Judas as confictio (Irenaeus, Adv. haer. I, 31, 1)' Acta Patristica et Byzantina 20, 122-126.

Wisse, F., 1971, 'The Nag Hammadi Library and the heresiologists', Vigiliae Christianae 25, 205-223.

Wurst, G., 2006, 'Irenaeus of Lyon and the Gospel of Judas', in R. Kasser, M. Meyer \& G. Wurst (transl.), The Gospel of Judas, pp. 121-135 (+ notes pp 171-173), National Geographic, New York.

Wurst, G., 2008, 'Irenaeus of Lyon and the Gospel of Judas', in R. Kasser, M. Meyer \& G. Wurst (transl.), The Gospel of Judas, pp. 169-179 (+ notes pp. 193-195), National Geographic, New York.

Wurst, G., 2012, 'Das Judasevangelium (CT 3)', in C. Markschies, J. Schröter \& A. Heiser (eds.), Antike christliche Apokryphen in deutscher Ubersetzung, vol. 2, pp. 12201234, Mohr, Tübingen. 